\title{
ANALISIS TEKS ARGUMENTASI DALAM TAJUK RENCANA HARIAN KOMPAS
}

\author{
Raisah Shalatun ${ }^{1}$ dan Syihabuddin ${ }^{2}$ \\ Program Studi Linguistik, Universitas Pendidikan Indonesia 1,2 \\ Surel: raisah.shalatun@upi.edu ${ }^{1}$ \\ syihabuddin@upi.edu ${ }^{2}$
}

\begin{abstract}
Abstrak
Tajuk rencana adalah opini redaksi yang memuat tentang pemikiran, pendapat dan sikap resmi dari suatu media berita terkait masalah yang terjadi di masyarakat. Bahasa yang digunakan dalam penulisan tajuk rencana berbentuk persuasif dan argumentatif. Penelitian ini bertujuan untuk menjelaskan tentang argumentasi dalam tajuk rencana harian Kompas. Penelitian ini menggunakan pendekatan metode deskriptif. Penelitian ini menghasilkan dua kesimpulan, yaitu metode argumentasi yang digunakan dalam harian Kompas berupa (1) genus atau definisi; (2) sebab akibat; (3) sirkumstansi atau keadaan; (4) persamaan; (5) perbandingan; (6) penentangan; (7) kesaksian; dan autoritas. Dalam satu tajuk rencana tidak hanya ditemukan satu teknik argumentasi, namun dapat lebih dari satu teknik argumentasi. Pola argumentasi yang digunakan dalam tajuk rencana harian Kompas terdiri dari beberapa komponen. Komponen dari argumen yang ditemukan antara lain: (1) pernyataan posisi; (2) data; (3) jaminan; (4) pendukung; (5) keterangan modalitas; dan (6) pengecualian atau bantahan. Pola argumentasi yang ditemukan pada tajuk rencana harian Kompas antara lain adalah PP-D (pernyataan posisi, data), PP-D-K (pernyataan posisi, data, keterangan), PP-D-J (pernyataan posisi, data, jaminan), PP-D-J-B (pernyataan posisi, data, jaminan dan bantahan), dan PP-D-J-P-K-B (pernyataan posisi, data, jaminan, pendukung, keterangan dan bantahan).
\end{abstract}

Kata Kunci: argumentasi, tajuk rencana, harian Kompas

\section{Abstract \\ Jurnal Ilmiah}

Pendidikan Bahasa, Sastra

An editorial is an editorial opinion that contains the thoughts, opinions, and official attitudes of news media regarding problems that occur in the community. The language used in writing the editorial is in the form of persuasive and argumentative. This study aims to explain the arguments in the editorial plan of the Kompas daily. This study uses a descriptive method approach. This research result brings two conclusions. Argumentation methods used in Kompas newspaper formed of (1) definition; (2) cause and effect; (3) circumstances; (4) equations; (5) comparisons: (6) opposition; and (7) authority. In one editorial, there is not only one argumentation technique, but more than one argumentation technique. The argumentation pattern used in the daily Kompas editorial consists of several components. The components of the arguments found include (1) claim; (2) data; (3) warrant; (4) backing; (5) modal qualifier; and (6) rebuttals. Argumentation patterns found in the editorial of Kompas daily include $C-D$ 
(claim, data), C-D- (claim, data, information), $C-D-W$ (claim, data, warrant), $C-D-W-R$ (claim, data, warrant, and rebuttal), and $C-D-W-B-M-R$ (claim, data, warrant, backing, modal qualifier, and rebuttal).

Keywords: argumentation, editorial, Kompas

\section{PENDAHULUAN}

Wacana adalah rangkaian kata atau tindak tutur yang mengungkapkan suatu tema dan yang disajikan secara teratur dan sistematis dalam satu kesatuan yang koheren, terdiri dari unsur-unsur bahasa segmental dan nonsegmental (Sobur, 2009, hlm. 11). Tajuk rencana adalah opini redaksi yang memuat tentang pemikiran, pendapat dan sikap resmi dari suatu media berita terkait masalah potensial, mengejutkan, aktual dan/atau kontroversial yang terjadi di masyarakat. Dalam buku "Editorial Writing" oleh Dr. Lyle Spencer, "Editorial adalah ekspresi fakta dan opini yang ringkas, logis dan menarik, sehingga pembaca biasa dapat dengan jelas memahami, terhibur, dan terpengaruh opini saat membaca berita yang penting (Effendy, 2000, hlm. 134). Maka dari itu, bahasa yang digunakan dalam penulisan tajuk rencana berbentuk persuasif dan argumentatif.

Argumentasi merupakan teknik menulis dalam upayanya Jumntuk mempengaruhi pembaca. Keraf Ir(2000; hlm. 3) menyatakan bahwa, "Argumentasi merupakan opini dan pernyataan yang dirancang untuk mempengaruhi orang lain agar mempercayai dan pada akhirnya bertindak sesuai dengan keinginan penulis atau pembicara. Dalam merangkai kalimat argumentatif, diperlukan kecermatan dalam menganalisis bukti-bukti dan fakta yang terdapat di lapangan agar argumen yang disajikan menjadi lebih kuat dan terpercaya. Pada teks tajuk rencana dapat ditemukan beberapa metode argumentasi, yaitu genus atau definisi, sebab akibat, sirkumstansi atau keadaan, persamaan, perbandingan, penentangan, kesaksian dan autoritas (Keraf, 2007, hlm. 108).

Setiap metode argumentasi terdapat fakta yang memperkuat topik dari suatu tajuk rencana. Dalam suatu tajuk rencana penulis dapat mengaplikasikan minimal satu atau bahkan lebih dari satu metode argumentasi dan merangkainya menjadi satu susunan. Susunan ini membentuk pola. Pola yang digunakan meliputi beberapa komponen. Komponen dari argumen yang dikemukakan oleh Toulmin et al. (1979) antara lain (1) claim atau pernyataan posisi, (2) data atau fakta, (3) warrant atau jaminan, (4) backing atau pendukung, (5) modal qualifier atau keterangan modalitas, dan (6) rebuttal atau pengecualian atau bantahan.

Penelitian sebelumnya dilakukan oleh Lupita dan Dawud (2018), Hasanah dan dawuder(2017). Berdasarkan penelitian Pertiwi dan Dawud (2018) yang berjudul Argumentasi dalam Teks Tajuk Rencana Harian Suara Merdeka, diperoleh kesimpulan: (1) teknik argumentasi dapat berupa teknik rasionalisasi, teknik identifikasi, teknik sugesti, teknik konformitas, teknik penggantian, dan teknik proyeksi, dan (2) pola argumentasi dapat dikategorikan menjadi tujuh, yaitu 
pola rasionalisasi, pola identifikasi, pola sugesti, pola konformitas, pola kompensasi, pola penggantian, dan pola proyeksi.

Mengacu pada penelitian Hasanah dan Dawud (2017), maka disimpulkan: (1) metode argumentasi dapat berupa metode pembuktian dengan pendefinisian, sebab dan akibat, persamaan, pertentangan, perbandingan, kesaksian, dan otoritas, serta (2) pola argumentasi dapat berupa pola sederhana dan pola kompleks.

Berdasarkan penjelasan di atas, penelitian ini berfokus pada argumentasi dalam teks tajuk rencana harian Kompas. adapun tujuan penelitian ini adalah (1) untuk mendeskripsikan metode argumentasi yang berupa yaitu genus atau definisi, sebab akibat, sirkumstansi atau keadaan, persamaan, perbandingan, penentangan, kesaksian dan autoritas, (2) mendeskripsikan pola argumentasi yang berupa claim atau pernyataan posisi, data atau fakta, warrant atau jaminan, backing atau pendukung, modal qualifier atau keterangan modalitas, dan rebuttal atau pengecualian atau bantahan.

\section{METODE}

Penelitian ini menggunakan metode penelitian kualitatif (Anggito, Albi, dan lik Johan Setiawan. 2018). Dengan menggunakan metode kualitatif, peneliti dapat menjelaskan secara lebih mendalam dan komprehensif tentang metode argumentasi dan pola argumentasi dalam tajuk rencana harian Kompas sesuai dengan hasil yang diperoleh dan menekankan pada hasil penelitian. Dalam penelitian ini penulis menggunakan analisis teks. Alasan pemilihan jenis analisis adalah penelitian ini yang bertujuan untuk menganalisis data tertulis seperti teks, buku, koran, surat, majalah sesuai dengan konteksnya.

Data penelitian ini berbentuk paragraf yang di dalamnya terdapat metode penegasan dalam argumentasi yaitu penegasan dengan genus atau definisi, penegasan dengan sebab akibat, penegasan dengan sirkumstansi atau keadaan, penegasan dengan persamaan, penegasan dengan perbandingan, penegasan dengan penentangan, dan penegasan dengan kesaksian dan autoritas dan pola argumentasi dari susunan paragraf yang di antaranya mencakup komponen claim atau pernyataan posisi, data atau fakta, warrant atau jaminan, backing atau pendukung, modal qualifier atau keterangan modalitas, dan rebuttal atau pengecualian atau bantahan.

Teknik pengumpulan data yang digunakan oleh peneliti dalam penelitian ini adalah studi dokumen, yaitu peneliti mengumpulkan dokumen dari tajuk rencana harian Kompas untuk dikaji. Adapun prosedur pengumpulan data dilakukan dengan cara (1) mengunjungi dan membaca halaman kompas.id; (2) mengumpulkan teks tajuk rencana yang akan dianalisis; (3) mengklasifikasi teks tajuk rencana yang akan dianalisis; (4) memberikan kode pada setiap tajuk rencana yang akan dikaji; (5) menandai metode penegasan argumentasi dan pola argumentasi dalam tajuk rencana; merekam data ke tabel analisis; (6) mengelompokkan data berdasarkan metode penegasan argumentasi dan pola argumentasi; serta (7) memberikan kode dan melakukan analisis.

Instrumen penelitian ini adalah 
peneliti sendiri. Alasannya adalah karena dalam penelitian ini peneliti berperan penting dalam penentuan masalah, fokus penelitian, menentukan sumber data, mengumpulkan data, melakukan analisis data, menjelaskan data, serta membuat kesimpulan atas seluruh hasil penelitian ini.

\section{HASIL DAN PEMBAHASAN}

Berdasarkan hasil analisis, ditemukan tujuh metode argumentasi dalam tajuk rencana harian Kompas, yakni genus atau definisi, sebab akibat, sirkumstansi atau keadaan, persamaan, perbandingan, penentangan, kesaksian dan autoritas.

\section{Metode Argumentasi Genus atau Definisi}

Genus atau definisi merupakan metode argumentasi yang digunakan penulis untuk membuat pembaca yakin dengan memberikan penjelasan, keterangan dan pemaparan suatu objek atau suatu topik permasalahan. Penyajian argumentasi dengan metode definisi dalam tajuk rencana ditandai dengan uraian penulis secara luas tentang suatu objek atau topik permasalahan yang dibicarakan. Dalam menggunakan metode definisi penulis dapat memaparkan definisi dari suatu objek atau topik permasalahanic dengan menggunakan ciri-ciri dari objek tersebut.

Di luar dugaan, debat perdana antara Presiden Donald Trump dari Partai Republik dan penantangnya, Joe Biden dari Partai Demokrat, menjadi ajang pertengkaran, saling mengejek dan menghina. Banyak orang kecewa karena acara debat selama 90 menit pada Selasa malam (Rabu pagi WIB) di Cleveland,
Ohio, itu tanpa fokus dan kehilangan substansi. Penuh kegaduhan dan saling memotong pembicaraan. (TR04)

QAnon adalah kelompok teori konspirasi yang meluas, yang percaya Presiden AS Donald Trump sedang melakukan perang rahasia melawan elite yang melakukan kejahatan internasional, paedofil, serta pemuja setan di pemerintahan, bisnis, dan media. (TR14)

Data (01) merupakan tajuk rencana tentang Terperangah Atas Debat Pilpres AS. Penulis berupaya menyampaikan pemikiran dan opininya tentang debat perdana antara Presiden Donald Trump dengan Joe Biden yang di luar dugaan malah menjadi ajang pertengkaran. Pada data ini metode definisi digunakan penulis untuk memberikan penjelasan dan gambaran terkait kejadian yang terjadi, ditandai dengan penjelasan kejadiankejadian yang terjadi selama debat berlangsung.

Data (02) merupakan tajuk rencana tentang Media Sosial Bersih Bagi Demokrasi. Penulis berupaya menyampaikan opini dan argumennya dengan cara menyampaikan informasi mengenai QAnon kepada pembaca. Penulis menggunakan metode pendefinisian titentang 'QAnon' sebagai suatu kelompok agar pembaca memahami siapa itu 'QAnon'. Dalam paragraf tersebut terdapat kata kunci adalah yang digunakan penulis untuk mendefinisikan QAnon. Metode ini membantu penguatan argumen, dengan pendefinisian pembaca menjadi lebih mudah memahami suatu permasalahan yang dibahas dalam suatu tajuk rencana. 


\section{Metode Sebab Akibat}

Metode sebab akibat adalah cara yang digunakan untuk meyakinkan pembaca dengan menjelaskan hubungan penyebab dan cakupan akibat yang ditimbulkan oleh objek atau suatu masalah. Tanda penggunaan metode sebab akibat dalam suatu tajuk rencana adalah dengan memberikan pernyataan-pernyataan yang menghubungkan sebab dan akibat dari objek atau suatu masalah. Dalam hal ini penulis dapat menyajikan argumentasi dari akibat lalu diikuti sebab atau pun sebaliknya sebab diikuti akibat.

Kompetisi ibarat urat nadi cabang olahraga. Tanpa kompetisi, klub tidak bisa menjalankan aktivitas hakiki mereka: berlatih dan bertanding. Jika klub tak bisa berkegiatan, yang terdampak sudah pasti pemain, juga pelatih. Di sekitar mereka ada asisten pelatih, pelatih fisik, pelatih kiper, masseur (juru pijat), dan banyak kru pendukung lainnya. (TR01).

Indonesia perlu menimba pengalaman dari banyak negara itu. Semakin tinggi kasus baru, semakin besar pula para pemimpin negara terinfeksi dan hal ini tentu bisa membahayakan kondisi sebuah negara. Jumlah kasus baru Covid-19 di Brasil, misalnya, mencapai puncaknya pada Juli ketika Presiden Bolsonarö terinfeksi. Mulai Agustus, munculnyá jumlah kasus baru Covid-19 mengalami penurunan hingga saat ini. (TR07)

Data (03) menunjukkan pemikiran penulis yang menjelaskan sebab dan akibat yang terjadi bila suatu kondisi terpaksa dijalankan. Dalam paragraf tersebut penulis memaparkan permisalan jika dan maka. "Jika klub tidak bisa berkegiatan, yang terdampak sudah pasti pemain, juga pelatih...." Penulis menggambarkan suatu kemungkinan diawali sebab lalu diikuti akibat.

Data (04) menunjukkan usaha penulis untuk menyampaikan argumen tentang meningkatnya kasus Covid-19 di Indonesia. Pada paragraf ini penulis menjelaskan permasalahan dengan menggunakan metode sebab akibat. Pada data ini permasalahan yang dibahas adalah angka kasus Covid-19 yang terus bertambah. Penggunaan kata semakin tinggi berarti 'semakin bertambah' dan semakin besar berarti 'semakin banyak' memberikan gambaran kepada pembaca untuk memahami hubungan sebab akibat dari tingginya kasus Covid-19 yang dapat mengancam kondisi sebuah negara.

\section{Metode Sirkumstansi atau Keadaan}

Metode sirkumtansi atau keadaan adalah metode argumentasi yang digunakan penulis untuk menggambarkan suatu keadaan. Keadaan dapat digolongkan ke dalam proses sebab akibat. Dalam penulisan argumentasi dengan metode keadaan ini, penulis memaparkan suatu kondisi di mana tindakan atau faktafakta yang diberikan adalah pilihan terakhir dan tidak tersedia pilihan lain. Tanda penggunaan metode keadaan adalah dengan menyajikan pernyataan dan fakta cyang membuat suatu objek atau masalah hanya memiliki satu solusi.

Kita harus dapat segera mengendalikan pandemi Covid-19 sesuai dengan standar Organisasi Kesehatan Dunia (WHO). Kita tidak ingin kehilangan manfaat bonus demografi saat ini dan terhindar dari gagal menjadi negara kaya pada 2045. (TR03)

Di luar upaya itu, sepertinya ekosistem kopi masih perlu melakukan 
sesuatu agar mereka bisa menghadapi situasi berat ini. Semangat gotong royong sangat jelas tampak di kalangan mereka, tetapi dari berbagai diskusi diketahui semangat ini biasanya muncul di awal krisis. Oleh karena itu, bentuk baru dari solidaritas, baik oleh konsumen, industri, maupun petani, perlu dimunculkan kembali karena pandemi telah berumur tujuh bulan. Gerakan baru membutuhkan visi, bentuk, dan cara baru. (TR06)

Data (05) menunjukkan argumen penulis dalam menyikapi kondisi Covid19. Penulis menegaskan bahwa tidak ada pilihan lain, selain yang telah dituliskan oleh penulis. Dari data ini pilihan yang diberikan adalah mengendalikan pandemi Covid-19 sesuai dengan standar Organisasi Kesehatan Dunia (WHO). Penggunaan kata harus menunjukkan bahwa tidak ada pilihan lain yang dapat diambil untuk dijalani.

Data (06) menunjukkan argumen penulis dalam menyikapi kondisi ekosistem kopi yang menurun selama pandemi. Penulis menegaskan pilihan yang disediakan dengan kata perlu, bahkan penulis mengulanginya sebanyak dua kali. Kata perlu dalam kalimat “... sepertinya ekosistem kopi masih perlu melakukan sesuatu agar mereka bisa menghadapi situasi berat ini." dan "... Oleh karena itus, bentuk baru dari solidaritas, baik oleh konsumen, industri, maupun petani, perlu dimunculkan kembali..." menunjukkan bahwa tidak ada solusi lain selain yang diajukan penulis dalam tulisannya.

\section{Metode Persamaan}

Metode persamaan adalah metode argumentasi yang menggunakan persamaan pada suatu pernyataan mengenai suatu objek atau topik permasalahan yang sedang dibahas. Dalam metode ini ditandai dengan pemaparan penulis tentang kesamaan antara dua objek atau dua topik permasalahan. Metode ini menggunakan analogi, jika dua hal memiliki kemiripan dalam aspek tertentu, maka ada kemungkinan hal-hal tersebut memiliki kemiripan dalam aspek lainnya. Semakin banyak kesamaannya, semakin besar pula kemiripannya. Kekuatan argumentasi ini juga bergantung pada kebenaran dari topik yang dibandingkan.

Di luar itu, belajar dari berbagai kasus bisnis, baik di dalam negeri maupun luar negeri, saat menghadapi tantangan pandemi, inovasi adalah kunci agar ekosistem kopi selamat. Inovasi bisa dilakukan dengan berbagai cara, seperti memperkuat kanal digital, mengubah ukuran produk, membuat produk turunan, dan mengubah cara penjualan. Semua berujung pada kemampuan mereka memahami perubahan perilaku konsumen. (TR06)

Data (07) menunjukkan pemikiran penulis yang mengambil contoh lain dari suatu permasalahan yang sama. Penulis menegaskan dengan kalimat “...belajar dari berbagai kasus bisnis, baik di dalam negeris maupun luar negeri..." sebagai contoherdari permasalahan lain yang memiliki topik serupa. Objek yang ditekankan oleh peneliti adalah bisnis, baik di dalam maupun di luar negeri.

\section{Metode Perbandingan}

Metode perbandingan merupakan metode argumentasi yang dipakai untuk meyakinkan pembaca dengan memperlihatkan persamaan dan perbedaan suatu objek atau topik permasalahan yang 
dibahas. Metode perbandingan ditandai dengan adanya pernyataan yang membandingkan objek atau topik permasalahan. Dalam penggunaan metode ini, penulis bisa membandingkan minimal dua objek atau lebih.

Selandia Baru berpenduduk sekitar 5 juta orang. Jumlah ini sedikit dibandingkan negara berpenduduk ratusan juta atau milyaran orang. Siapa pun bisa mengatakan, dengan penduduk sesedikit itu, Selandia Baru tentu lebih gampang dikelola. Pandangan ini ada benarnya, tetapi tetap terdapat kesamaan prinsip penanganan pandemi yang bisa diterapkan di negara berpenduduk sedikit atau banyak. Prinsip penanganan pandemi Covid-19 ialah tes sebanyak mungkin, pelacakan, serta perawatan yang mumpuni. Tes besar-besaran untuk penelusuran kontak dekat penderita menjadi kunci pengendalian pandemi.

Virus korona menyadarkan kita, ada dimensi perang lain di luar perang yang harus ditempuh dengan penggunaan alutsista. Sebelum era pandemi, wacana perang ramai diwarnai oleh ancaman perang siber dan perang asimetrik, atau perang Generasi Keempat. Di lingkungan TNI sendiri, energi dan pikiran banyak dicurahkan untuk mencapai Kekuatan Pokok Minimum (MEF) yang ditargetkan rampung tahun 2024. (TR11)

Data (08) menunjukkan pemikiran penulis tentang kondisi penduduk Selandia Baru. Dalam paragraf tersebut penulis membandingkan jumlah penduduk Selandia Baru dengan negara lainnya yang berpenduduk milyaran.

Data (09) menunjukkan perbedaan yang dikemukakan penulis mengenai kondisi sebelum pandemi merebak. Jika sebelum pandemi negara-negara ramai dengan wacana perang dan ancaman perang, kini saat pandemi dunia jadi tersadar bahwa ada hal yang harus dihadapi selain perang.

\section{Metode Penentangan}

Metode penentangan adalah metode argumentatif yang digunakan penulis untuk meyakinkan pembaca dengan langkah menentang suatu objek atau masalah. Dalam metode ini, penulis memberikan fakta dan informasi tentang suatu objek atau masalah, kemudian memeriksa kelemahannya dan mulai membuat pernyataan yang bertentangan dengan objek atau masalah tersebut. Saat menggunakan metode ini, penulis dapat menentang objek atau masalah dengan mengajukan kondisi yang seharusnya atau yang berlawanan.

Tes RT-PCR mendeteksi keberadaan material genetik virus corona. Namun, selama ini, penggunaannya terkendala harga yang mahal dan belum meratanya kapasitas laboratorium pemeriksaan. Pada awal-awal pandemi, beberapa rumah sakit memasang harga Rp 2,5 juta meski sekarang sebagian turun menjadi sekitar Rp 1,4 juta. (TR12)

zan BalKomitmen Google tetap harus disambutalsebagai niat baik mendukung jurnalisme berkualitas. Namun, upaya menciptakan ekosistem media massa yang adil juga tetap harus berjalan karena ini juga penting untuk mendukung jurnalisme berkualitas. Tidak mungkin lahir jurnalisme berkualitas apabila daya hidup industri media massa terganggu. (TR14)

Data (010) menjelaskan tentang Pemeriksaan masif. Penulis berupaya menyampaikan pemikirannya dengan 
metode penentangan. Penulis menyampaikan argumennya dengan cara menuliskan fakta mengenai Tes RT-PCR. Dalam penentangan fakta ini penulis menggunakan kata namun, lalu menentang fakta tersebut dengan fakta lainnya yang berbanding terbalik untuk menguatkan argumennya.

Data (011) menjelaskan tentang Jurnalisme Berkualitas. Penulis berupaya menjelaskan argumennya tentang konten berkualitas di Google News. Penulis menggunakan metode penentangan dengan langkah menuliskan pernyataan posisi yang mendukung niat baik Google. Lalu, selanjutnya terdapat kata kunci namun yang digunakan penulis untuk menyajikan pernyataan lain tentang ekosistem media massa yang adil, yang mana pernyataan tersebut bertentangan dengan pernyataan sebelumnya.

\section{Metode Kesaksian dan Autoritas}

Metode kesaksian adalah metode argumentasi yang digunakan oleh penulis untuk meyakinkan para pembaca dengan menjelaskan fakta dan informasi mengenai permasalahan yang dibahas berdasarkan sudut pandang seseorang. Metode autoritas dipakai untuk meyakinkan pembaca dengan cara menyajikan pendapat seorang ahli atau pakarddari suatu bidang untuk menjelaskan objek atau topik permasalahan. Dalam metode kesaksian ini, penulis dapat menjelaskan kesaksian dari suatu permasalahan menggunakan kesaksian orang lain atau kesaksian dari penulis sendiri.

Trump bicara asal-asalan tentang Covid- 19, di antaranya dia katakan vaksin segera tersedia menjelang pemilu. Hal ini membuat risih pihak industri farmasi AS, diwakili Presiden BIO Michelle McMurry-Heath. "Kami tidak membiarkan keadaan yang tidak transparan tentang proses pengembangan vaksin," kata McMurry-Heath. Pemimpin Umum Pfizer, Albert Bourla, juga menyatakan agar vaksin jangan dipolitisasi. (TR08)

Sundar Pichai, CEO Google, di situs Google News Initiative, mengatakan, pihaknya berusaha memastikan konten berita berkualitas diakui di seluruh platform Google. Ini komitmen finansial terbesar Google untuk membayar konten berita; pada 2018, Google menginvestasikan 300 juta dollar AS. (TR14)

Data (012) membahas mengenai pernyataan Trump terkait Corona. Penulis berupaya menyampaikan pendapat dan opininya tentang Virus Corona Menguji Trump. Penulis menunjukkan pernyataan Trump terkait Corona yang membuat risi pihak industri farmasi. Penulis menggunakan kesaksian dari orang lain. Pada data ini kesaksian komentar Trump yang asal-asalan terkait vaksin Covid-19 yang menurutnya segera tersedia sebelum pemilu ditanggapi oleh Presiden BIO Michelle McMutty-Heath. Dalam paragraf tersebut penggunaan kata kata dan kami menunjukkan bahwa adanya respons dan tanggapan dari Presiden BIO Michelle McMurry-Heath. Adapun tanggapan lainnya yang dikemukakan oleh Pemimpin Umum Pfizer, Albert Boula yang ditandai dengan kata menyatakan.

Data (013) membahas mengenai Jurnalisme berkualitas. Penulis berupaya menyampaikan pendapatnya mengenai rencana Google dalam menyajikan konten 
berkualitas. Dalam paragraf ini penulis menyampaikan argumennya dengan mencantumkan kesaksian dari orang lain. Penggunaan kata "mengatakan" pada kalimat "Sundar Pichai, CEO Google, di situs Google News Initiative, mengatakan, pihaknya berusaha memastikan konten berita berkualitas diakui di seluruh platform Google" menunjukkan adanya pernyataan dari Sundar Pichai. Lalu kesaksian tersebut diikuti oleh argumen penulis sendiri.

\section{Pola Argumentasi}

Berdasarkan hasil analisis dari tajuk rencana harian Kompas, dihasilkan 6 pola. Hasil penelitian berupa pola simpel sampai pola kompleks berdasarkan teori Toulmin's Argument Pattern (TAP) 6 pola tersebut adalah PP-D, PP-D-K, PP-D-J, PP-D-J-B, PP-D-J-P-K-B.

\section{Argumentasi berpola PP-D}

Pola PP-D adalah pola argumentasi yang terdiri atas pernyataan posisi dan data. Toulmin menyatakan bahwa pola ini adalah pola yang paling sederhana. Penulis menyampaikan argumen atau pemikirannya dalam suatu kalimat yang berisi pernyataan posisi terhadap suatu permasalahan, kemudian dilengkapi dengan bukti yang berupa fakta ataudataion Bahasa, Sastra dengan bukti yang berupa fakta atauldataia dan Daerah

Tabel 1. Pola Argumentasi Tajuk Rencana Harian Kompas

\begin{tabular}{|c|c|c|c|c|c|c|}
\hline \multicolumn{3}{|c|}{ Komponen Argumentasi } & $\mathbf{P}$ & $\mathbf{B}$ \\
\hline Kalimat & $\mathbf{P}$ & $\mathbf{D}$ & $\mathbf{J}$ & $\mathbf{P}$ & $\mathbf{K}$ & $\mathbf{B}$ \\
\hline $\begin{array}{l}\text { Kenaikan kasus Covid-19 di Sabah menjadi peringatan jika Malaysia } \\
\text { ingin mempercepat pemilihan umum setelah muncul klaim dari } \\
\text { kelompok oposisi Anwar Ibrahim, yang akan melengserkan } \\
\text { pemerintahan Perdana Menteri Muhyiddin Yassin. }\end{array}$ & & & & & & \\
\hline 'Percepatan pemilu bisa menjadi langkah yang salah. & & & & \\
& & & & \\
\hline
\end{tabular}

dari pernyataan yang dikemukakan. Pola ini adalah pola yang paling dasar untuk menjadi bekal bagi seseorang dalam menyampaikan argumen. Pendapat atau pandangan penulis disampaikan dengan alasan dan bukti-bukti pendukung. Dalam suatu tajuk rencana, penempatan pernyataan posisi tidak selalu pada awal kalimat, diikuti fakta atau data. Posisinya bisa bertukar. Paragraf argumentasi dapat dimulai dengan data lalu pernyataan posisi atau dimulai dengan pernyataan posisi dan diikuti data.

Tabel 1 merupakan salah satu tajuk rencana dengan pola argumentasi PP-D. Argumen di atas diawali dengan data terkait kasus Covid-19 di Sabah yang menjadi peringatan jika Malaysia ingin mempercepat pemilihan umum, diikuti dengan pernyataan posisi yang menyatakan argumen penulis tentang pertimbangan percepatan pemilu, pernyataan posisi tersebut dilengkapi dengan bukti yang dipaparkan pada data, lalu ditutup dengan data yang menjelaskan hasil pemilu lokal di Sabah. Pola dasarnya adalah PP-D. 


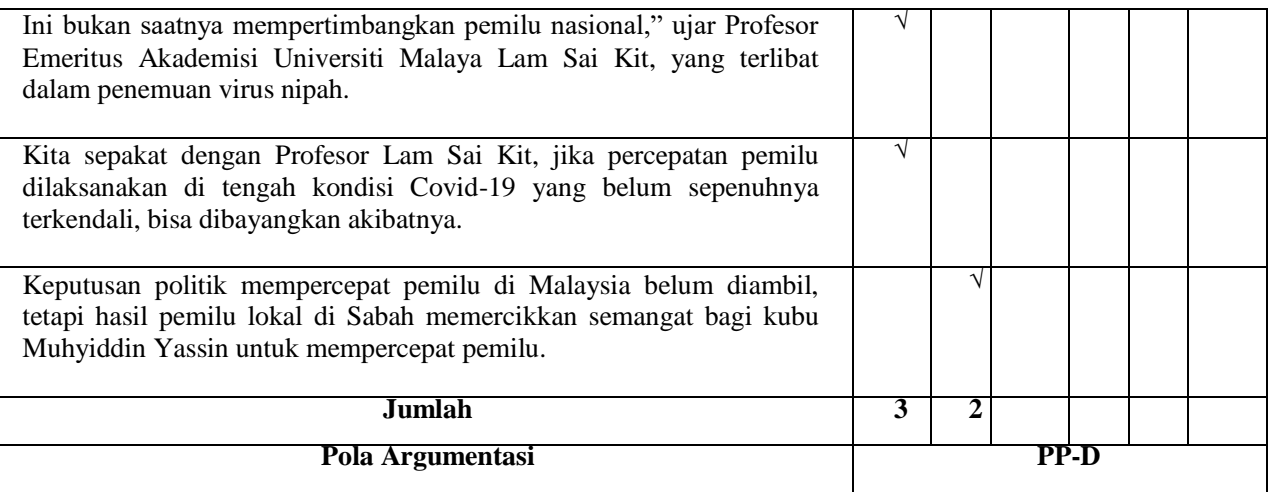

\section{Argumentasi berpola PP-D-K}

Pola argumentasi PP-D-K adalah pola argumentasi yang terdiri atas pernyataan posisi, data dan keterangan. Dasar dari pola ini adalah pernyataan posisi, diikuti data dan keterangan. Keterangan adalah kata atau frasa yang menerangkan pernyataan posisi.

Tajuk rencana pada tabel 2 membahas tentang pembatalan kompetisi sepak bola Shopee Liga 1 dan Liga 2. Tajuk rencana diawali dengan data yang menunjukkan fakta dan situasi sebenarnya mengenai kompetisi sepak bola Shopee yang dibatalkan. Lalu, paragraf diikuti dengan pernyataan posisi yang menunjukkan argumen penulis, diikuti dengan keterangan-keterangan untuk memperkuat pernyataan posisi, lalu penulis menambahkan pernyataan posisi dan menutup tajuk rencana dengan data dengan bukti-bukti yang memperkuat pernyataan

posisi.

Tabel 2. Pola Argumentasi Tajuk Rencana Harian Kompas

\begin{tabular}{|c|c|c|c|c|c|c|}
\hline \multicolumn{7}{|l|}{ Komponen Ärgumentasi } \\
\hline Kalimat & $\mathbf{P}$ & $\mathbf{D}$ & $\mathrm{J}$ & $\mathbf{P}$ & $\mathbf{K}$ & $\mathbf{B}$ \\
\hline $\begin{array}{l}\text { Pembatalan kompetisi sepak bola Shopee Liga } 1 \text { dan Liga } 2 \\
\text { menimbulkan konsekuensi klub yang mati suri dan nasib pemain } \\
\text { yang makin tak menentu. }\end{array}$ & & $\sqrt{ }$ & & & & \\
\hline $\begin{array}{c}\text { Batalnya liga dipastikan setelah Kepolisian RI tidak menerbitkan } \\
\text { izin keramaian. }\end{array}$ & & $\sqrt{ }$ & & & & \\
\hline $\begin{array}{l}\text { Kepala Divisi Humas Polri Inspektur Jenderal Raden Prabowo } \\
\text { Argo Yuwono mengatakan, izin keramaiand tidak dikeluarkan S } \\
\text { karena situasi pandemi Covid-19, yang kasusinyal masih cerus } \\
\text { meningkat. }\end{array}$ & $\begin{array}{ll}\sqrt{1} \\
\text { tra }\end{array}$ & & & & & \\
\hline $\begin{array}{l}\text { Kompetisi ibarat urat nadi cabang olah raga. Tanpa kompetisi, klub } \\
\text { tidak bisa menjalankan aktivitas hakiki mereka: berlatih dan } \\
\text { bertanding. }\end{array}$ & & & & & $\sqrt{ }$ & \\
\hline $\begin{array}{l}\text { Jika klub tak bisa berkegiatan, yang terdampak sudah pasti pemain, } \\
\text { juga pelatih. }\end{array}$ & & & & & $\mathrm{v}$ & \\
\hline $\begin{array}{l}\text { Di sekitar mereka ada asisten pelatih, pelatih fisik, pelatih kiper, } \\
\text { masseur (juru pijat), dan banyak kru pendukung lainnya. }\end{array}$ & & & & & $\sqrt{ }$ & \\
\hline Kompetisi juga mendrong perputaran modal. & $\sqrt{ }$ & & & & & \\
\hline $\begin{array}{l}\text { Sebuah pertandingan sepak bola menjadi sumber pemasukan bagi } \\
\text { tim tuan rumah (home) seiring kehadiran tim tamu (away) beserta } \\
\text { fasilitas yang menyertai, seperti akomodasi, konsumsi, dan biaya } \\
\text { perjalanan. }\end{array}$ & & $\vec{v}$ & & & & \\
\hline
\end{tabular}




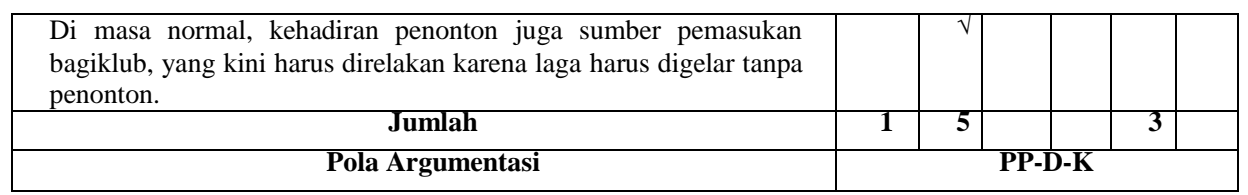

\section{Argumentasi berpola PP-D-J}

Pola argumentasi PP-D-J adalah pola yang memiliki tiga elemen, yaitu pernyataan posisi, data, dan jaminan. Jaminan atau elemen ketiga merupakan jaminan yang memuat pernyataan umum yang menghubungkan pernyataan posisi dan data.
Dapat disimpulkan jaminan disini berfungsi sebagai penghubung yang memuat pernyataan umum yang dikemukakan oleh para ahli agar dapat diyakini kebenarannya. Tajuk Rencana dengan pola argumentasi PP-D-J ditunjukan pada tabel 3 .

Tabel 3. Pola Argumentasi Tajuk Rencana Harian Kompas

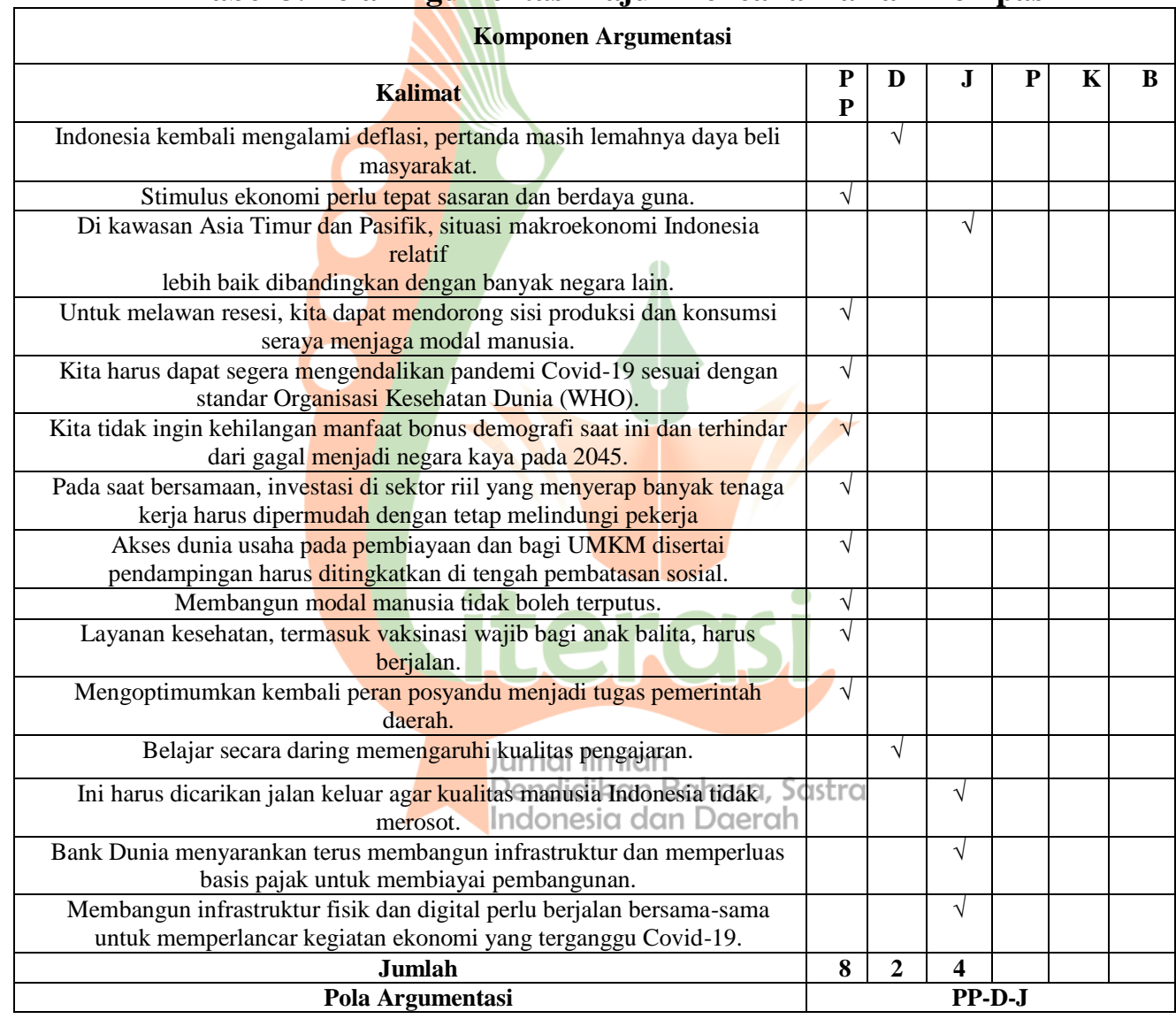

\section{Argumentasi berpola PP-D-J-B}

Pola argumentasi PP-D-J-B adalah pola argumentasi yang memuat pernyataan posisi, data, jaminan dan bantahan. Penulis menyampaikan pikirannya dalam suatu kalimat yang berisi pernyataan posisi terhadap suatu permasalahan, kemudian dilengkapi data yang berupa bukti atau fakta dari pernyataan yang dikemukakan, disertai jaminan untuk memperkuat data, dan bantahan yang dapat menguatkan 
argumen penulis.

Pola argumentasi tajuk rencana pada tabel 4 diawali dengan pernyataan posisi yang menjelaskan tentang ucapan Trump tentang Covid-19. Lalu didukung dengan data yang berupa perkataan dari McMurry-Heath dan pemimpin umum Pfizer, Albert Boula terkait vaksin. Lalu, penulis menambahkan jaminan atas pernyataan posisi, jaminan tersebut menambahkan pernyataan Trump yang menyepelekan Covid-19. Lalu, penulis menutup argumennya dengan bantahan yang diambil dari pernyataan Biden terkait kematian akibat Covid-19.

Tabel 4. Pola Argumentasi Tajuk Rencana Harian Kompas

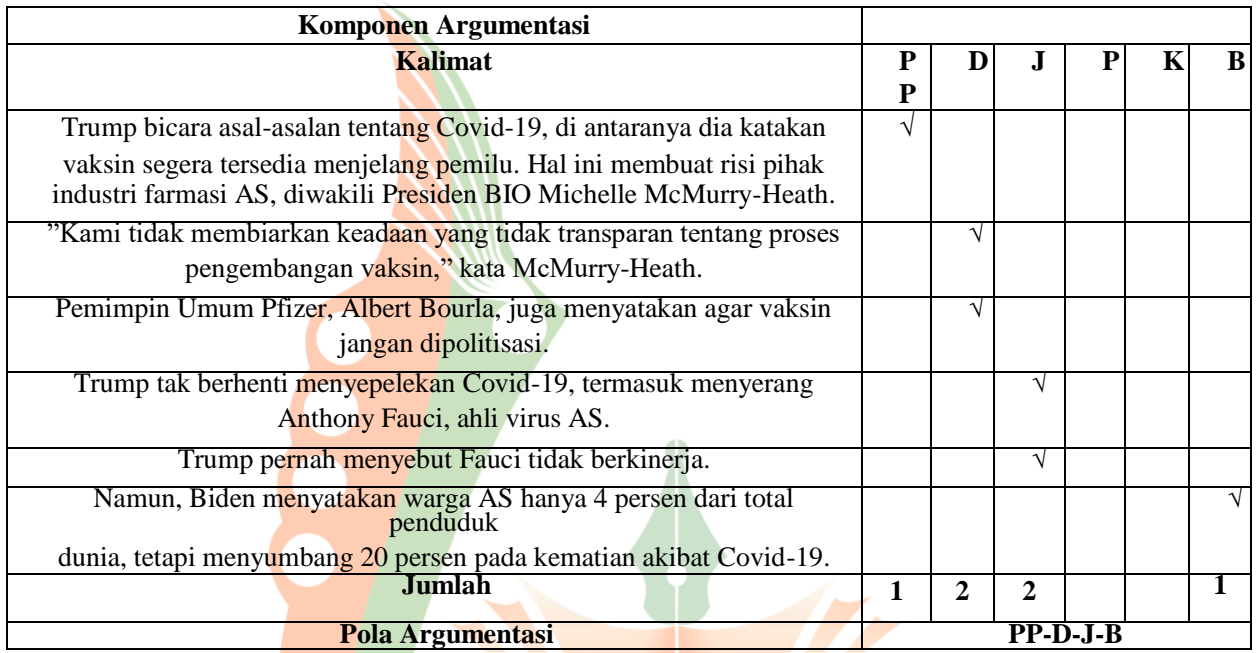

Pola argumentasi tajuk rencana P-D-JB

Pola argumentasi tajuk rencana pada tabel 5 merupakan pola P-D-J-B. Pada tajuk rencana ini penulis menuangkan pemikirannya mengenai RUU Cipta Kerja. Tajuk rencana ini diawali dengan pernyataan posisi dari penulis/ngyang menyatakan tentang pola "mumpung berkuasa" yang menjadi strategi pengambilan keputusan politik yang meninggalkan rakyat. Penulis memperkuat pernyataannya dengan data dan jaminan. Kemudian, penulis menambahkan argumennya dalam bentuk pernyataan posisi terkait kesuksesan pemerintah dalam mengesahkan sejumlah RUU, tidak lupa penulis menambahkan jaminan dari pernyataannya yang menunjukkan bahwa rakyat hanya berperan sebagai konsumen politik, lalu ditambahkan data yang berupa bukti atas pernyataan-Presiden Jokowi dalam sebuah debatcalon presiden. Pada akhir tajuk rencana, penulis menambahkan bantahan yang berupa pertanyaan terkait dialog Presiden Jokowi. Bantahan ini memperkuat argumen penulis karena pertanyaan yang dituliskan mempertanyakan dialog Presiden Jokowi yang hasilnya berbeda di lapangan, hal ini memperkuat pernyataan penulis. 
Tabel 5. Pola Argumentasi Tajuk Rencana Harian Kompas

\begin{tabular}{|c|c|c|c|c|c|c|}
\hline \multicolumn{7}{|l|}{ Komponen Argumentasi } \\
\hline Kalimat & $\underset{\mathbf{p}}{\mathbf{P}}$ & $\mathbf{D}$ & J & $\mathbf{P}$ & $\mathbf{K}$ & $\mathbf{B}$ \\
\hline $\begin{array}{c}\text { Kita tidak, berharap pola "mumpung berkuasa" atau "mumpung } \\
\text { mayoritas" menjadi strategi pengambilan keputusan politik yang } \\
\text { meninggalkan rakyat. }\end{array}$ & $\sqrt{ }$ & & & & & \\
\hline $\begin{array}{l}\text { RUU Cipta Kerja yang dibahas dengan mekanisme omnibus-satu UU } \\
\text { yang merevisi sejumlah UU-adalah eksperimen konstitusional yang } \\
\text { dilakukan Presiden Jokowi. }\end{array}$ & & $\mathrm{V}$ & & & & \\
\hline $\begin{array}{l}\text { Dengan mekanisme seperti itu, sistematika RUU Cipta Kerja tidak } \\
\text { mudah dipahami. }\end{array}$ & & & $\sqrt{ }$ & & & \\
\hline $\begin{array}{c}\text { RUU Cipta Kerja bukan hanya membahas soal substansi } \\
\text { ketenagakerjaan, melainkan juga merambah sejumlah aturan lain, } \\
\text { termasuk produk halal, } \\
\text { tenaga nuklir, tata ruang, soal imigrasi, hak paten, hak adat, dan sejumlah } \\
\text { substansi lain. }\end{array}$ & & $\sqrt{ }$ & & & & \\
\hline $\begin{array}{l}\text { RUU Cipta Kerja memberikan gambaran corak UU yang kapitalistik, } \\
\text { resentralisasi, tetapi juga etatisme. }\end{array}$ & & $\sqrt{ }$ & & & & \\
\hline $\begin{array}{l}\text { Kesuksesan pemerintah dan DPR mengesahkan sejumlah RUU boleh jadi } \\
\text { merupakan perwujudan corak demokrasi kaum elite, bukan demokrasi } \\
\text { yang partisipatoris. }\end{array}$ & $\sqrt{ }$ & & & & & \\
\hline $\begin{array}{l}\text { Partai politik dan pemerintah merasa berhak menentukan serta } \\
\text { merumuskan apa saja sesuai dengan kehendak kaum elite. }\end{array}$ & $\sqrt{ }$ & & & & & \\
\hline $\begin{array}{l}\text { Pola pendekatan politik kekuasaan yang diterapkan jauh dari prinsip } \\
\text { musyawarah mufakat, sila keempat Pancasila. }\end{array}$ & $\sqrt{ }$ & & & & & \\
\hline Jauh dari prinsip negosiasi di antara berbagai kepentingan. & $\mathrm{V}$ & & & & & \\
\hline Rakyat hanya dikonstruksikan sebaga1 konsumen politık belaka. & & & $\mathrm{V}$ & & & \\
\hline $\begin{array}{c}\text { Praktik demokrasi kaum elite jauh dari praktik politik yang pernah } \\
\text { dijalankan Presiden Jokowi. }\end{array}$ & & & $\sqrt{ }$ & & & \\
\hline $\begin{array}{l}\text { Dalam sebuah debat calon presiden, Presiden Jokowi mendefinisikan } \\
\text { demokrasi secara sederhana, yakni mendengar suara rakyat. }\end{array}$ & & $\mathrm{V}$ & & & & \\
\hline $\begin{array}{c}\text { Praktik itu bukan hanya diucapkan, melainkan sudah dipraktikkan } \\
\text { Presiden Jokowi saat menjadi Wali Kota Solo ketika berunding } \\
\text { memindahkan } \\
\text { sebuah pasar di Solo melalui proses vang panjang dan sabar. }\end{array}$ & & $\mathrm{V}$ & & & & \\
\hline $\begin{array}{c}\text { Pertanyaannya, mengapa pendekatan dialog yang sudah dilakukan } \\
\text { Presiden Jokowi selama ini, kini berubah? }\end{array}$ & & & & & & $\sqrt{ }$ \\
\hline Jumlah & 5 & 5 & 3 & & & 1 \\
\hline Pola Argumentasi & & & PP-D & -B & & \\
\hline
\end{tabular}

\section{Argumentasi berpola PP-D-J-P-K}

Pola argumentasi PP-D-J-P-K adalah kalimat yang berisi pernyataan posisi terhadap suatu topik permasalahan, dilengkapi data atau fakta, jaminan untuk pernyataan posisi, data, jaminan.lmimemperkuat data, pendukung yang
pendukung dan keterangan. Pendidika memperkuatkan argumen penulis, lalu pendukung dan keterangan. Penulis sia dan paierah menyampaikan pikirannya dalam suatu keterangan.

Tabel 6. Pola Argumentasi Tajuk Rencana Harian Kompas

\begin{tabular}{|c|c|c|c|c|c|c|}
\hline \multicolumn{7}{|l|}{ Komponen Argumentasi } \\
\hline Kalimat & $\begin{array}{l}\mathbf{P} \\
\mathbf{P}\end{array}$ & D & $\mathbf{J}$ & $\mathbf{P}$ & $\mathbf{K}$ & B \\
\hline $\begin{array}{c}\text { Kabar gembira dari Organisasi Kesehatan Dunia, yang pekan lalu } \\
\text { mengeluarkan Daftar Penggunaan Darurat pertama untuk tes diagnostik } \\
\text { cepat berbasis antigen. }\end{array}$ & & $\sqrt{ }$ & & & & \\
\hline
\end{tabular}


Senin (28/9/2020), Direktur Jenderal Organisasi Kesehatan Dunia (WHO) Tedros Adhanom Ghebreyesus mengumumkan kesepakatan antara WHO dan mitranya, antara lain Global Fund, Bill \& Melinda Gates Foundation, Pusat Pengendalian dan Pencegahan Penyakit (CDC) Afrika, serta produsen uji diagnostik cepat Abbott dan SD Biosensor, untuk penyediaan 120 juta tes cepat antigen dengan harga murah selama enam bulan bagi

negara berpenghasilan rendah dan menengah.

Tes untuk mengidentifikasi keberadaan virus itu dapat memberikan hasil dalam waktu 15-30 menit. Jauh lebih cepat dibandingkan dengan tes reaksi berantai polimerase
transkripsi terbalik (RT-PCR).

Tes yang dikembangkan kedua produsen itu disebut sangat portabel, andal, dan mudah dijalankan sehingga memungkinkan perluasan pengujian, terutama di negara yang tak memiliki banyak laboratorium atau petugas

terlatih untuk melaksanakan tes PCR.

Bagi Indonesia, penggunaan tes cepat antigen menguntungkan karena mempercepat dan memperluas pelaksanaan tes Covid-19.

Tracing (pelacakan kasus) lebih efektif sehingga isolasi dan treatmenr (pengobatan) bisa lebih cepat sebelum penderita ataupun orang tanpa gejala

menularkan virus ke sekitarnya.

\begin{tabular}{|c|c|c|c|c|c|}
\hline $\begin{array}{c}\text { WHO merekomendasikan pemeriksaan minimal } 1 \text { per } 1.000 \text { penduduk } \\
\text { per } \\
\text { minggu. }\end{array}$ & & & $\sqrt{ }$ & & \\
\hline $\begin{array}{c}\text { Jika penduduk Indonesia berjumlah } 269,6 \text { juta jiwa, artinya } 269.600 \\
\text { orang } \\
\text { harus diperiksa setiap minggu, atau } 38.514 \text { orang per hari. }\end{array}$ & & & $\sqrt{ }$ & & \\
\hline $\begin{array}{c}\text { Sampai } 29 \text { September } 2020 \text {, di Indonesia ada } 343 \text { laboratorium } \\
\text { pemerintah } \\
\text { atau swasta yang melaksanakan tes, baik PCR maupun tes cepat } \\
\text { molekuler. }\end{array}$ & & & $\sqrt{ }$ & & \\
\hline Yang diperiksa pada hari itu 37.158 spesimen dari 27.891 orang. & & $\sqrt{ }$ & & & \\
\hline $\begin{array}{l}\text { Perbedaan jumlah itu karena satu kasus dapat diambil lebih dari satu kali } \\
\text { dan lebih dari satu jenis spesimen (usap hidung, tenggorokan ataupun } \\
\text { dahak). }\end{array}$ & & & & & $\sqrt{ }$ \\
\hline $\begin{array}{c}\text { Presiden Joko Widodo menetapkan target pemeriksaan } 30.000 \text { orang per } \\
\text { hari. }\end{array}$ & (e) & $\sqrt{ }$ & & & \\
\hline $\begin{array}{l}\text { Sejak } 1 \text { April hingga } 29 \text { September 2020, baru } 1.962 .754 \text { orang dites di } \\
\text { Indonesia. }\end{array}$ & 4 & $\sqrt{ }$ & & & \\
\hline $\begin{array}{c}\text { Ada beberapa hal yang perlu diperhatikan. Menurut laman CDC } \\
\text { Amerika } \\
\text { Serikat, tes antigen untuk SARS-CoV-2 umumnya kurang sensitif, } \\
\text { yakni 84-97,6 persen, dibandingkan dengan RT-PCR, memungkinkana, } \\
\text { hasil } \\
\text { negatif palsu. Namun, spesivitasnya } 100 \text { persen sehingga tidak ada } \\
\text { positif palsu. }\end{array}$ & Sastrit & a & & $\sqrt{ }$ & \\
\hline Namun, spesivitasnya 100 persen sehingga tidak ada positif palsu. & & & & $\sqrt{ }$ & \\
\hline $\begin{array}{l}\text { Panduan Tata Laksana Pemeriksaan Antigen Rapid Test SARS-CoV-2 } \\
\text { yang diterbitkan Perhimpunan Dokter Spesialis Patologi Klinik dan } \\
\text { Kedokteran Laboratorium Indonesia pada 12 Agustus } 2020 \\
\text { menyebutkan perlu laboratorium dengan fasilitas biological safety } \\
\text { cabinet (BSC) } 2 \text { untuk } \\
\quad \text { pemeriksaan antigen. }\end{array}$ & & & & $\sqrt{ }$ & \\
\hline $\begin{array}{l}\text { Oleh karena menyangkut sampel virus, perlu diperhatikan keamanan } \\
\text { petugas dan limbahnya. Saat ini beredar sejumlah tes cepat antigen } \\
\text { dengan } \\
\text { sensitivitas bervariasi, } 30-84 \text { persen. }\end{array}$ & & $\sqrt{ }$ & & & \\
\hline
\end{tabular}




\begin{tabular}{|c|c|c|c|c|c|c|}
\hline $\begin{array}{c}\text { Untuk itu, penting konsisten menggunakan tes antigen yang } \\
\text { direkomendasikan WHO. }\end{array}$ & $\sqrt{ }$ & & & & \\
\hline Jumlah & $\mathbf{5}$ & $\mathbf{6}$ & $\mathbf{5}$ & $\mathbf{3}$ & $\mathbf{1}$ & \\
\hline Pola Argumentasi & \multicolumn{4}{|c|}{ PP-D-J-P-K } \\
\hline
\end{tabular}

\section{Argumentasi berpola PP-D-J-P-B}

Pola argumentasi PP-D-J-P-B adalah pola argumentasi yang terdiri dari pernyataan posisi, data, jaminan, pendukung, keterangan dan bantahan. Pola argumentasi PP-D-J-P-B adalah pola argumentasi yang terdiri dari pernyataan posisi, data, jaminan, pendukung dan keterangan. Penulis menyampaikan pikirannya dalam suatu kalimat yang berisi pernyataan posisi terhadap suatu topik permasalahan, dilengkapi data atau fakta, jaminan untuk memperkuat data, pendukung yang memperkuatkan argumen penulis, lalu keterangan.

\section{Tabel 7. Pola Argumentasi Tajuk Rencana Harian Kompas}

\begin{tabular}{|c|c|c|c|c|c|c|}
\hline \multicolumn{7}{|l|}{ Komponen Argumentasi } \\
\hline Kalimat & $\begin{array}{l}\mathbf{P} \\
\mathbf{P}\end{array}$ & $\mathbf{D}$ & J & $\mathbf{P}$ & $\mathbf{K}$ & B \\
\hline Selandia Baru berpenduduk sekitar 5 juta orang. & & $\sqrt{ }$ & & & & \\
\hline $\begin{array}{l}\text { Jumlah ini sedikit dibandingkan negara berpenduduk ratusan juta atau } \\
\text { miliaran orang. }\end{array}$ & $\sqrt{ }$ & & & & & \\
\hline $\begin{array}{c}\text { Siapa pun bisa mengatakan, dengan penduduk sesedikit itu, Selandia } \\
\text { Baru } \\
\text { tentu lebih gampang dikelola. }\end{array}$ & & & & & & $\sqrt{ }$ \\
\hline $\begin{array}{c}\text { Pandangan ini ada benarnya, tetapi tetap terdapat kesamaan prinsip } \\
\text { penanganan pandemi yang bisa diterapkan di negara berpenduduk } \\
\text { sedikit } \\
\text { atau banyak. }\end{array}$ & $\sqrt{ }$ & & & & & \\
\hline $\begin{array}{c}\text { Prinsip penanganan pandemi Covid-19 ialah tes sebanyak mungkin, } \\
\text { pelacakan, serta perawatan yang mumpuni. }\end{array}$ & & & $\sqrt{ }$ & & & \\
\hline $\begin{array}{c}\text { Tes besar-besaran untuk penelusuran kontak dekat penderita menjadi } \\
\text { kunci } \\
\text { pengendalian pandemi. }\end{array}$ & & & $\sqrt{ }$ & & & \\
\hline Perawatan yang baik akan mengurangi jumlah kematian. & & & $\sqrt{ }$ & & & \\
\hline $\begin{array}{l}\text { Di sisi lain, ada bentuk intervensi yang tak boleh dilupakan, yakni } \\
\text { karantina } \\
\text { wilayah atau pengetatan sosial. }\end{array}$ & & & $\sqrt{ }$ & & & \\
\hline $\begin{array}{c}\text { Kebijakan ini bertujuan menekan sesedikit mungkin potensi kontak } \\
\text { antar } \\
\text { manusia. }\end{array}$ & & & & $\sqrt{ }$ & & \\
\hline $\begin{array}{l}\text { Langkah itu dilandasi fakta bahwa pemicu utama penularan Covid-19 } \\
\text { tak Jurnal Ilmiah } \\
\text { lain ialah manusia, bukan hewan, apalagi tumbuhanBahasa. }\end{array}$ & astr & $\sqrt{ }$ & & & & \\
\hline $\begin{array}{c}\text { Agar penularan menurun, pembatasan pergerakan-manusia sangat } \begin{array}{c}\text { perc } \\
\text { penting } \\
\text { dilakukan. }\end{array}\end{array}$ & $\sqrt{1}$ & & & & & \\
\hline $\begin{array}{l}\text { Selandia Baru melakukan pembatasan sosial, bahkan karantina, dengan } \\
\text { baik. }\end{array}$ & & $\sqrt{ }$ & & & & \\
\hline $\begin{array}{c}\text { Warganya mematuhi seruan jaga jarak dan penggunaan masker dari } \\
\text { pemerintah. }\end{array}$ & $\sqrt{ }$ & & & & & \\
\hline $\begin{array}{c}\text { The New York Times menyebut, pesan yang jelas mengenai protokol } \\
\text { kesehatan dan tidak bertolak belakang diperlukan agar masyarakat } \\
\text { patuh. }\end{array}$ & & $\sqrt{ }$ & & & & \\
\hline $\begin{array}{l}\text { Pesan yang bertolak belakang, menurut The New York Times terjadi } \\
\text { ketika pemerintah meminta rakyat menjaga jarak dan memakai masker, } \\
\text { tetapi sejumlah pejabatnya berkumpul tanpa jaga jarak serta } \\
\text { mengabaikan } \\
\text { penggunaan masker. }\end{array}$ & & & & & & $\sqrt{ }$ \\
\hline Jumlah & 4 & 4 & 4 & 1 & & 2 \\
\hline Pola Argumen & & & -1 & $-\mathrm{K}=$ & & \\
\hline
\end{tabular}




\section{PENUTUP}

\section{Simpulan}

Teknik argumentasi yang digunakan dalam harian Kompas berupa genus atau definisi, sebab akibat, sirkumstansi atau keadaan, persamaan, perbandingan, penentangan, kesaksian dan autoritas. Dalam satu tajuk rencana tidak hanya ditemukan satu Teknik argumentasi, namun dapat lebih dari satu Teknik argumentasi.

Pola argumentasi yang digunakan dalam tajuk rencana harian Kompas terdiri dari beberapa komponen. Komponen dari argumen yang ditemukan antara lain (1) claim atau pernyataan posisi; (2) data atau fakta; (3) warrant atau jaminan; (4) backing atau pendukung; (5) modal qualifier atau keterangan modalitas; dan (6) rebuttal atau pengecualian atau bantahan. Pola argumentasi yang ditemukan pada tajuk rencana harian Kompas antara lain adalah PP-D (pernyataan posisi, data), PP-D-K (pernyataan posisi, data, keterangan), PP-D- J (pernyataan posisi, data, jaminan), PP-D-J-B (pernyataan posisi, data, jaminan dan bantahan), $\mathrm{PP}-\mathrm{D}_{-} \mathrm{J}_{-} \mathrm{P}_{4}$ K-B (Pernyataan posisi, data, jaminainlikan Bahasa, Sastra pendukung, keterangan dan bantahan). Pola tersebut merupakan pola- pola dasar. Pada tajuk rencana harian Kompas, polanya tidak selalu berurutan dari pernyataan posisi, argumen yang dikemukakan penulis dapat dibuka dari komponen lain dan acak.

\section{DAFTAR PUSTAKA}

Anggito, A. \& J. S. (2018). Metodologi penelitian kualitatif. Sukabumi: CV Jejak.

Effendy, O. U. (2000). Ilmu, teori dan filsafat komunikasi. Bandung: PT Citra Aditya Bakti.

Keraf, G. (2000). Argumentasi dan narasi komposisi lanjutan iii. Jakarta: Gramedia Pustaka Utama.

Keraf, G. (2007). Argumentasi dan narasi (cetakan ke). Jakarta: Gramedia Pustaka Utama.

Miftahul Hasana \& Dawud. (2017). Argumentasi dalam artikel opini surat kabar media indonesia. Bibliotika: Jurnal Kajian Perpustakaan Dan Informasi.

Pertiwi, L. B., \& Dawud, D. (2018). Argumentasi dalam teks tajuk rencana harian suara merdeka. Basindo: Jurnal Kajian Bahasa, Sastra Indonesia, Dan Pembelajarannya.

Sobur, A. (2009). Analisis teks media (kelima). Bandung: PT Remaja Rosdakarya.

Toulmin, S. E. (2003). The uses of argument: Updated edition. In The Uses of Argument: Updated Edition. 